\title{
Journal of the Brazilian Chemical Society: an Example of Success in the Brazilian Chemistry
}

Another cycle of the Journal of the Brazilian Chemical Society (JBCS) is closed with our voluntary departure from the editorship in this last issue of 2012. We have been part of it since 1987, when it was conceived by Professor Eduardo Motta Alves Peixoto, its first editor. Now we can proudly say that we are leaving the Journal as the best chemistry journal in Latin America and among the BRICS bloc.

The creation of the JBCS was possible thanks to the Program for the Support of Scientific and Technological Development - PADCT, by means of the public notice QEQ 01/87-10 to "support the scientific dissemination". ${ }^{1}$

The launching of a journal in English when Química Nova, in Portuguese, was a success was not unanimously supported by the Brazilian chemistry community as it could be imagined nowadays.

On the other hand, there was no guarantee that the JBCS project of the Brazilian Chemical Society would be approved because the Brazilian Chemical Association (ABQ) was also proposing the revitalization of the Annals of the Brazilian Chemical Association. But the fact that the editorial board of the English-language journal being proposed had four Nobel Prize winners was enough for the BCS project to be approved.

Though having been approved on the evaluation of the proposals submitted to the QEQ 01/87-10, an appeal considerably delayed the announcement of the final result.

The signing of the contract with the Research and Project Financing Agency-FINEP on February 17, 1989 occurred at a time of high inflation in Brazil, so the resources released by PADCT barely paid the four first issues of the Journal, released in 1990 with an initial print run of 2000 copies.

The continuity of the Journal was only possible because Professor Eduardo Peixoto managed to get funds from ICI of Brazil.

In 1995, there was the first big change in the Journal with the departure of Professor Eduardo Peixoto, who had been transferred from Sao Paulo to Rio de Janeiro.

The second cycle of JBCS started with the Journal consolidated and, already in the following year, 1996, being published bimonthly. And that was only possible because of the paved way left by Eduardo Peixoto.

JBCS's indexing first in the Current Contents, then in the Web of Science set up its internationalization. ${ }^{2}$
The Journal's third change came about with the transfer of its office from São Paulo to Campinas, the joining of other Editors and the alternation of the editorial coordination between Professors Angelo da Cunha Pinto and Jailson Bittencourt de Andrade.

During that new cycle, priority was given to the Journal promotion abroad, to the BCS website free access, to the publication time reduction and to the regularity of the issue release, which resulted, among other improvements, in the explosion of submissions from abroad, even surpassing the submissions from Brazilian authors.

With its 23 years of existence, JBCS is the best proof that high quality Brazilian journals are feasible and that the free access philosophy, so much discussed all over the world nowadays, has always been defended by the JBCS editors: a borderless science. ${ }^{3}$

Feeling that our mission in the editorship of the Journal has been completed, we are sure there is no way backwards. The fact that JBCS reached 2012 with a monthly periodicity has changed the Brazilian journals' paradigm.

To those who will lead JBCS from now on, we assure this fourth change will bring more and more improvement.

We are grateful to the BCS Board and Council for the unconditional trust along all these years, to the other editors, to all editorial board members, to the Office staff, to the referees for their anonymous work and, mainly, to the authors, who, with their work, brought prestige to JBCS and so are the real source of its great success.

Our gratitude to all. Ahead to the future...

Angelo C. Pinto

JBCS Editor

Jailson B. de Andrade JBCS Editor

\section{References}

1. Pinto, A. C.; Peixoto, E. M. A.; Galembeck, F.; De Andrade, J. B. De Paoli, M. A.; Avaca, L. A.; Alves, O. L.; Quim. Nova 1997, 20,81.

2. Pinto, A. C.; Cunha, A. S.; Quim. Nova 2008, 31, 2221.

3. Pinto, A. C.; Zucco, Z.; Galembeck, F.; de Andrade, J. B.; Vieira, P. C.; Quim. Nova, 2012, 35, 2092. 